\title{
Artifak Purba Pasemah: Analisis Ungkap Rupa Patung Megalitik di Pasemah
}

\author{
Erwan Suryanegara*, Nuning Damayanti** \& Wiyoso Yudoseputro***
}

\author{
*Jurusan Senirupa Universitas Pendidikan Indonesia \\ ** KK Senirupa-Fakultas Senirupa dan Desain ITB \\ *** Gurubesar Senirupa Institut Kesenian Jakarta
}

\begin{abstract}
Prehistoric relics, especially those of megalithic traditions, were found many in the plateau of Pasemah. From several types of megalithic artefacts, megalithic idols are the one that excessively found in Pasemah. Unfortunately, scientific information about these ancient artefacts in Pasemah is still scarcely to be found, especially in the form of visual data and reports. Based upon this notion, this research conducted a study to investigate, document and describes the existence, depiction, the object, expression style, symbol, and attribute of the megalithic idols of Pasemah; using the approach of ungkap rupa.
\end{abstract}

The study discovers that the proponent society of megalithic culture in Pasemah had used and applied bronze. They had good ability in chiseling idols from big stones of andesit, formed it in sharp corners and created accurate forms. The depicted idols show that its form has a dynamic pictorial postures and shapes, although some are also made in the style of realistic expression. The idols are formed in a leaning forwards posture, its head or face tilted upward, and its feet usually visualized in the bended forms, depicting austronesoid man and animals complete with its attribute and symbols.

Further, the study indicates that these megalithic idols were representations of symbolic-mystical beliefs of a Pasemah's society which were based on cosmology of the past. Accordingly, these idols were inseparable parts of Pasemah's ancestor veneration rituals. The distinctiveness of these idols is found in their dynamics - both in pictorial and realistic depiction — that seem to be the masterpiece of megalithic idols of Pasemah at that time. The idols visualize the complete body part of austronesoid man and/or animals (head, body, foot/feet, and hand), which indicates that the megalithic idols of Pasemah represents a mystical culture of a society that whorshiped the spirit of their ancestors, live as an agrarist society of farmer (peladang) system, and encourages the patriotic characteristic of man.

Keywords: Pasemah; culture of megalithic; idol of megalithic. 


\section{$1 \quad$ Pendahuluan}

Zaman purba atau zaman prasejarah (prehistory), adalah zaman sebelum dimulainya sejarah yang tertulis, sehingga tidak terdapat peninggalan tertulis mengenai kehidupan manusia pada zaman itu. Masa prasejarah ini memiliki rentang waktu jauh lebih lama dan panjang dalam sejarah perjalanan serta perkembangan manusia dibandingkan dengan masa sejarah. Dengan berbekal akal, manusia menciptakan segala sesuatunya guna pemenuhan kebutuhan dan kepentingan hidupnya, baik yang bersifat lahiriah (fisik) maupun batiniah (spiritual), dan yang demikian ini dalam batasan tertentu disebut kebudayaan.

Di Indonesia, peninggalan budaya prasejarah ini ditemukan menyebar hampir ke seluruh wilayah kepulauan Nusantara, seperti di Leang-leang - Sulawesi Selatan dan pantai selatan pulau Irian (Wiyoso Yudoseputro, 1983); pantai Kalimantan, Sulawesi, dan Irian (Pindi Setiawan, 1994 - 1998); Poso Sulawesi Tengah, Bogor - Jawa Barat, dan masih banyak lagi yang lainnya termasuk tentunya yang ada di wilayah dataran tinggi Pasemah, Kabupaten Lahat dan Kota Pagaralam - Provinsi Sumatra Selatan.

Pasemah adalah satu wilayah di Kabupaten Lahat dan Kota Pagaralam, Provinsi Sumatra Selatan. Daerah ini secara georafis merupakan suatu wilayah dataran tinggi, dan posisinya masih satu rangkaian dengan Bukit Barisan di pulau Sumatra. Hutan alam tropis dengan kondisi perbukitan batu-batu cadas, merupakan satuan batuan beku dengan jenis batuan andesit, dan dilalui oleh beberapa anak sungai (wilayah Batang Hari Sembilan), adalah daerah yang subur dan sangat potensial bagi kehidupan masyarakat purba atau prasejarah, dalam upaya pemenuhan kebutuhan hidup mereka yang secara naluriah dan adaptif masih lebih mengandalkan ketersediaan bahan makanan dari alam.

Di bumi Pasemah ini banyak ditemukan artifak purba tinggalan budaya Megalitikum (Batu Besar), seperti: Patung Batu, Kubur Batu, Lukisan Dinding Kubur Batu, Batu Bergores, Gambar Gores di Dinding Cadas, Dolmen, Lumpang Batu, Menhir, dan lain sebagainya. Wilayah sebar budaya Megalitikum Indonesia ditemukan di beberapa tempat diantaranya: Sumatra, Nias, Jawa, Bali, Sumba, Sulawesi, dan lain-lain. R.P. Soejono mengatakan, “di Indonesia tradisi megalitik muncul setelah tradisi bercocok-tanam atau bertani food-froducing mulai meluas, diperkirakan sejak zaman Neolitikum sampai dengan zaman Logam - Perunggu”.

Luasnya wilayah sebar dan banyaknya temuan artifak megalitik di bumi Pasemah ini, tentunya memunculkan banyak pula permasalahan yang menarik untuk dikaji. Penelitian terdahulu yang pernah dilakukan baik oleh peneliti asing atau pun oleh para peneliti yang berasal dari Balai Arkeologi Palembang 
dan Puslit Arkeologi Nasional Jakarta, baru membicarakannya melalui pendekatan keilmuan arkeologi, antropologi, dan sosiologi, seperti yang beberapa kali ditulis dan diterbitkan melalui jurnal berita penelitian arkeologi. Artifak-artifak megalitik tersebut belum pernah diteliti dan dikaji secara mendalam dengan menggunakan pendekatan ilmu seni rupa.

Mengungkap rupa merupakan upaya menjelaskan suatu yang semula tidak diketahui, terutama tentang karya rupa yang kasat mata dan diharapkan dapat lebih mengungkap maknanya. Melalui analisa ungkap rupa, dikaji atau diungkapkan segala sesuatu yang melingkupi patung megalitik peninggalan budaya prasejarah di Pasemah, baik dalam hal perupaan, nilai estetis, makna simbolis, dan termasuk pula nilai-nilai magis - mistis sesuai nilai-nilai kosmologi yang menyertainya.

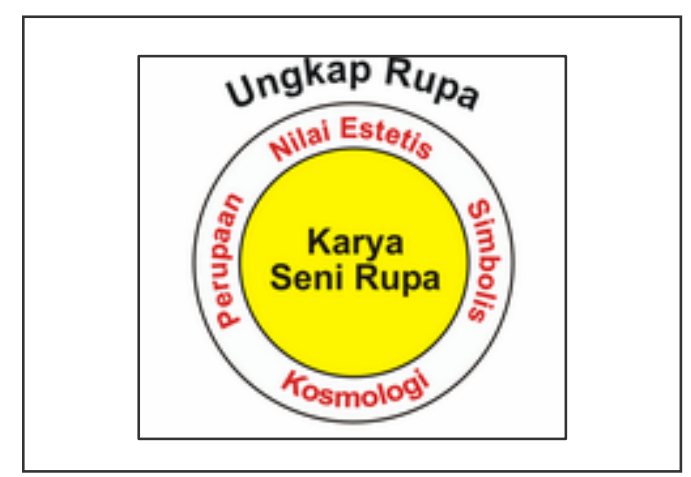

Gambar 1 Skema ungkap rupa.

Manusia pendukung budaya megalitik sudah mengenal dan bahkan sudah memanfaatkan alat kerja yang terbuat dari bahan logam. Mereka sudah memiliki kemampuan sangat baik dalam memahat batu-batu besar dengan sudut-sudut yang tajam atau runcing, dan secara bentuk patung-patung itu tampak sudah memiliki garis-garis kontur yang begitu dinamis. Untuk dapat menghasilkan artifak-artifak patung seperti itu tentunya membutuhkan mata pahat yang bukan sekedar terbuat dari batu api saja, namun menggunakan pahat bermata logam yang sangat memungkinkan untuk itu. Namun bila dilihat dari sifat, bentuk, dan termasuk perkiraan fungsinya, artifak-artifak megalitik itu memperlihatkan adanya kelanjutan dari budaya sebelumnya yakni zaman Batu Baru.

Selain kecenderungan di atas, pada batu gores, gambar di dinding kubur batu maupun patung-patung batu besar tersebut, terlihat adanya atribut yang mengindikasikan terbuat dari bahan logam atau perunggu (nekara, pedang, gelang, kalung, dan anting-anting), baik yang dikenakan maupun sedang dibawa 
oleh orang atau tokoh seperti sosok yang mereka patungkan atau pahatkan. Para peneliti terdahulu juga menyebutkan, bahwa patung megalitik merupakan satu jenis artifak dari temuan tinggalan yang terbanyak jumlah satuannya, dibandingkan artifak megalitik lainnya di Pasemah.

\section{Kebudayaan Prasejarah}

Ketika manusia awal memulai hidup dan kehidupannya di muka bumi, mereka adalah pioneer tentu sangat wajar bila dalam berbagai hal menyangkut kehidupannya masih hidup dalam taraf serba sederhana. Secara kodrati dalam hidupnya manusia memiliki kebutuhan-kebutuhan baik yang bersifat material (fisik) maupun spiritual (rohani). Untuk pemenuhan kebutuhan-kebutuhannya itu, maka manusiapun menciptakan segala sesuatu sesuai kebutuhan atau membuat piranti sebagai alat bantunya. Keberadaan piranti-piranti itu ada yang berwujud (kongkrit) benda-benda dan ada pula yang tak berwujud (abstrak) seperti aturan-aturan, nilai-nilai, bahasa, kesenian, kepercayaan, dan sebagainya. Sehubungan dengan hal-hal yang menyangkut kebutuhan dan upaya pemenuhan kebutuhan hidup manusia itulah, yang kemudian dalam batasan tertentu disebut kebudayaan.

Hubungan masyarakat dengan kebudayaannya merupakan suatu kesatuan yang erat, sehingga keduanya tidak mungkin dipisahkan. Mengingat kenyataan itu bahwa tulisan yang menjadi bagian kebudayaan manusia itu tidak serta merta ada, melainkan berkembang dari yang sederhana hingga tulisan yang kompleks. Masa ditemukannya tulisan dalam satu kebudayaan, kerap disebut sebagai era sejarah. Oleh karenanya di dalam sejarah perkembangan kebudayaan para ahli membaginya menjadi dua bagian besar, yaitu kebudayaan zaman prasejarah "nirleka" (nir = tidak ada, leka = tulisan) dan kebudayaan zaman sejarah. ${ }^{[15]}$

Berdasarkan hasil-hasil penelitian pada temuan artifak purba para ahli prasejarah sepakat, bahwa pada saat kebudayaan Neolitikum masih berlangsung ternyata manusia prasejarah memiliki pula kecenderungan memanfaatkan batu besar dalam aktivitas kehidupannya, khususnya yang berkaitan dengan keberadaan "arwah" dalam aktivitas kerohaniannya. Penggunaan media yang berupa batu-batu besar dikenal sebagai era kebudayaan Batu Besar (Megalitikum). Tradisi penggunaan batu besar ini ternyata terus berlangsung hingga masuk ke zaman kebudayaan logam, bahkan menurut para ahli di zaman Logam inilahlah kebudayaan Megalitikum itu mencapai puncak kesempurnaannya, mengingat sudah dipergunakannya alat-alat yang terbuat dari bahan logam. 


\begin{tabular}{|c|c|c|c|}
\hline $\begin{array}{l}\text { Zaman } \\
\text { Logam }\end{array}$ & \multirow{3}{*}{ 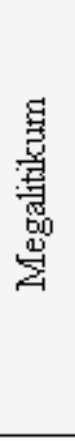 } & $\begin{array}{l}\text { Benda-benda } \\
\text { perhiasan } \\
\text { manık-manik } \\
\text { bejana, candrasa } \\
\text { nekara, moko } \\
\text { kapak corong }\end{array}$ & \multirow{3}{*}{$\begin{array}{l}\text { menhir } \\
\text { dolmen } \\
\text { keranda } \\
\text { kubur batu } \\
\text { gambar di dinding kubur } \\
\text { gambar gores di batu } \\
\text { punden berundak } \\
\text { patung } \\
\text { manik-manik }\end{array}$} \\
\hline \multirow[t]{2}{*}{ Neolitikum } & & $\begin{array}{l}\text { Benda-benda perhiasan } \\
\text { tembikar } \\
\text { kapak persegi }\end{array}$ & \\
\hline & & kapak lonjong & \\
\hline \multicolumn{2}{|l|}{ Mesolitikum } & \multicolumn{2}{|c|}{$\begin{array}{l}\text { gambar di dinding \& langit-langit gua serta di dinding bukit cadas } \\
\text { flakes, alat dari tulang } \\
\text { pebble (kapak Sumatra) }\end{array}$} \\
\hline \multicolumn{2}{|l|}{ Paleolitikum } & \multicolumn{2}{|l|}{$\begin{array}{l}\text { flakes, alat dari tulang } \\
\text { choppers (batu penetak) }\end{array}$} \\
\hline
\end{tabular}

Gambar 2 Skema periode dan hasil kebudayaan prasejarah Indonesia (Diadaptasi dari R. Soekmono, 1973).

Sistem budaya masa prasejarah adalah sistem budaya mistis yang berkaitan erat dengan sistem kepercayaan mistis. Menurut Jakob Sumardjo: "Dalam masyarakat dengan konteks budaya mistis ini terdapat cara berpikir berdasarkan kesatuan kosmos. Mikrokosmos (manusia), makrokosmos (semesta), dan metakosmos (alam lain) menjadi satu keutuhan”. Konsep adanya kehidupan sesudah kematian, sesungguhnya berawal dari masa prasejarah ini. Cara berpikir bahwa ada sesuatu kekuatan di luar diri manusia dan menguasai mereka yang masih hidup merupakan norma-norma yang dijunjung tinggi dan utama dalam hidup dan kehidupan manusia purba, sebagai sebuah sistem kepercayaan.

Demikian halnya artifak purba yang ada di Pasemah sebagai suatu hasil kebudayaan manusia di masa prasejarah yang bersifat fisik atau material, sesungguhnya juga menyiratkan spirit atau nilai-nilai yang berlaku saat itu. Sistem nilai (norma, adat-istiadat, kepercayaan) di masa prasejarah yang tercermin pada benda-benda tinggalannya merupakan satu kesatuan dalam sistem kebudayaan yang didukung dan dijunjung oleh masyarakatnya, yakni sistem kebudayaan masyarakat prasejarah . 


\section{Dataran Tinggi Pasemah}

Dataran tinggi Pasemah secara politis berada di dalam wilayah administrasi pemerintahan Kabupaten Lahat dan Kota Pagaralam, Provinsi Sumatra Selatan. Secara geografis bumi Pasemah berada di dalam rangkaian atau masih merupakan kelanjutan dari gugusan Bukit Barisan yang membentang memanjang di sisi sebelah Barat Sumatra. Keberadaan gunung Dempo yang masih aktif dan menjulang tinggi diantara perbukitan yang ada, dengan puncaknya yang mencapai ketinggian 3.159 meter dari permukaan laut, serta ditambah adanya tiga buah sungai besar Musi, Lematang, dan Enim, kemudian dilengkapi pula dengan beberapa anak sungainya. Seakan merangkai menyatukan bumi Pasemah yang subur menghijau, dan menjadikannya sebagai wilayah yang memiliki kandungan alam melimpah.

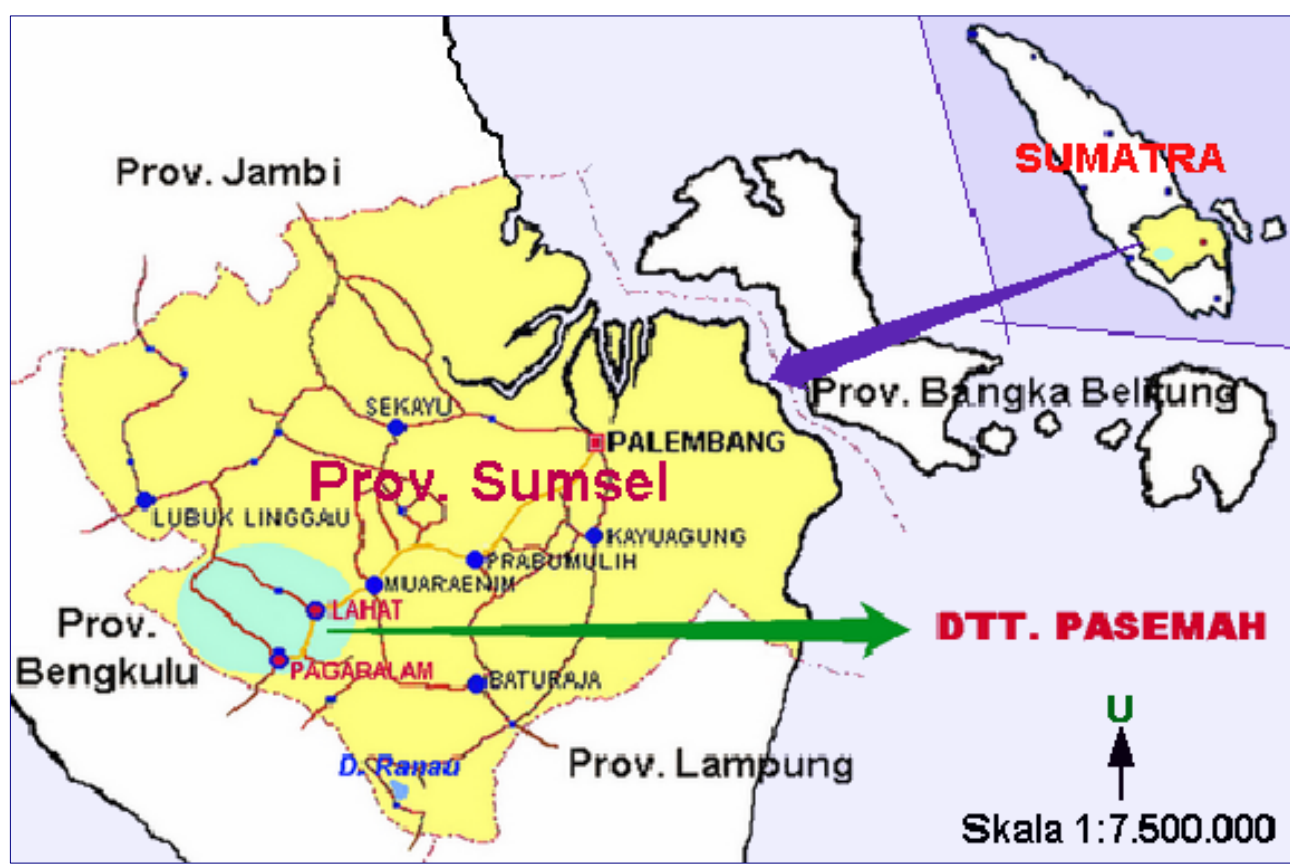

Gambar 3 Peta lokasi dataran tinggi Pasemah di Provinsi Sumatra Selatan.

\section{$4 \quad$ Wilayah Sebar dan Lingkungan Situs di Pasemah}

Menurut para peneliti terdahulu seperti A. N. J. Th. A. Th Van der Hoop (1930 - 1931), dikatakan bahwa di bumi Pasemah ini ditemukan 22 (dua puluh dua) buah lingkungan situs megalitik dari masa prasejarah. Demikian pula pada kegiatan survei situs-situs Megalitik di Kabupaten Lahat - Provinsi Sumatra Selatan, yang dilakukan oleh tim peneliti dari Proyek Balai Arkeologi 
Palembang di tahun 1996, dilaporkan bahwa telah berhasil disuvei sebanyak 19 (sembilan belas) lingkungan situs. Berdasarkan studi literatur ternyata tidak seluruh situs yang ada tersebut memiliki artifak yang berupa patung megalitik, dan disebutkan pula bahwa di beberapa situs yang memang memiliki artifak patung megalitik, sebagian kondisi patungnya sudah tidak lengkap dan rusak berat, sehingga sangat sulit untuk dikenali wujudnya.

Demikian pula ketika dilakukan studi lapangan terhadap 12 (dua belas) lingkungan situs, baik di wilayah kabupaten Lahat maupun di kota Pagaralam, seperti situs Belumai, Geramat, Karang Dalam, Muara Danau, Pagaralam Pagun, Tanjung Ara, Tanjung Sirih (oleh beberapa peneliti sebelumnya sering disebut juga sebagai situs Pulaupanjang), Tanjung Telang, Tebat Sibentur, Tebing Tinggi, Tegur Wangi, dan Tinggi Hari. Di antara beberapa situs tersebut ada yang kondisi patungnya rusak parah, bahkan sebagian besar kepalanya sudah hilang, sehingga akan menyulitkan ketika melakukan identifikasi secara men-detail. Ada juga yang patungnya sebagian besar masih terkubur di dalam tanah atau belum diangkat ke permukaan, serta dijumpai pula beberapa situs yang memang tidak memiliki artifak patung megalitik. Peta di bawah ini adalah dua lingkungan situs dari beberapa lingkungan situs yang ada di Pasemah.

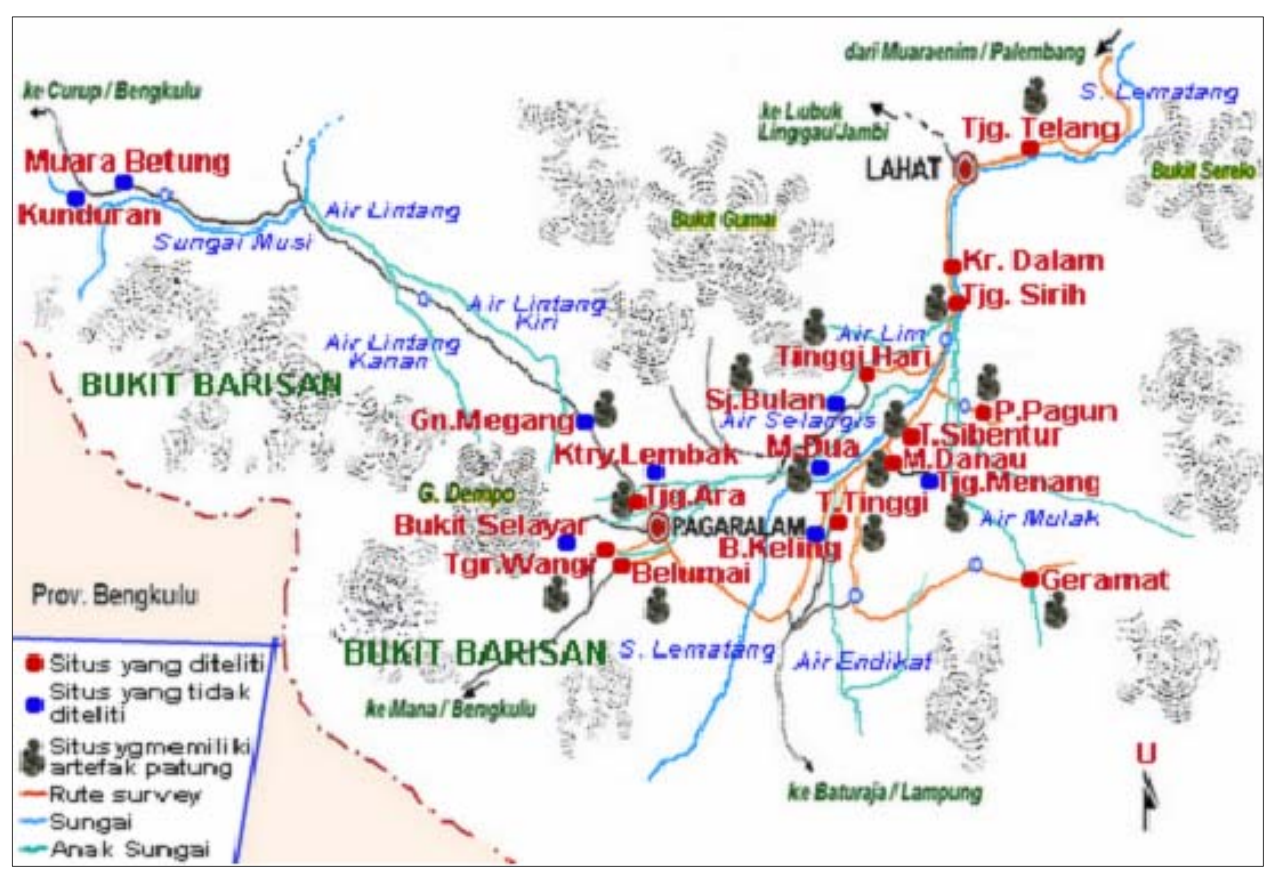

Gambar 4 Wilayah sebar situs prasejarah Pasemah. (Erwan Suryanegara, 2006) 
Menurut Van der Hoop, umumnya material batuan yang ada di bumi Pasemah tergolong batuan beku dari jenis batuan "andesit”, yang secara visual ciricirinya dapat dikenali melalui warna batu-batuan tersebut. Batuan jenis andesit ini cenderung berwarna putih keabu-abuan menuju kehitam-hitaman, biru gelap, kuning, dan atau coklat kemerah-merahan. Berdasarkan analisis kimiawi yang dilakukan oleh Colonial Institute, Amsterdam yang bekerja sama dengan Mineralogical and Geological Institute of The State - University, Utrecht, terhadap batuan yang contohnya berasal dari situs Tegur Wangi, dapat diketahui bahwa jenis batuan andesit di Pasemah ini terbentuk atas senyawa beberapa unsur kimia seperti: $\mathrm{SiO} 2, \mathrm{~Pb}, \mathrm{Ca}, \mathrm{Na}, \mathrm{Fe}, \mathrm{Al}$, dan $\mathrm{K}$. Batuan beku jenis batuan andesit ini memang tergolong jenis batu yang baik untuk dijadikan bahan pembuatan patung .

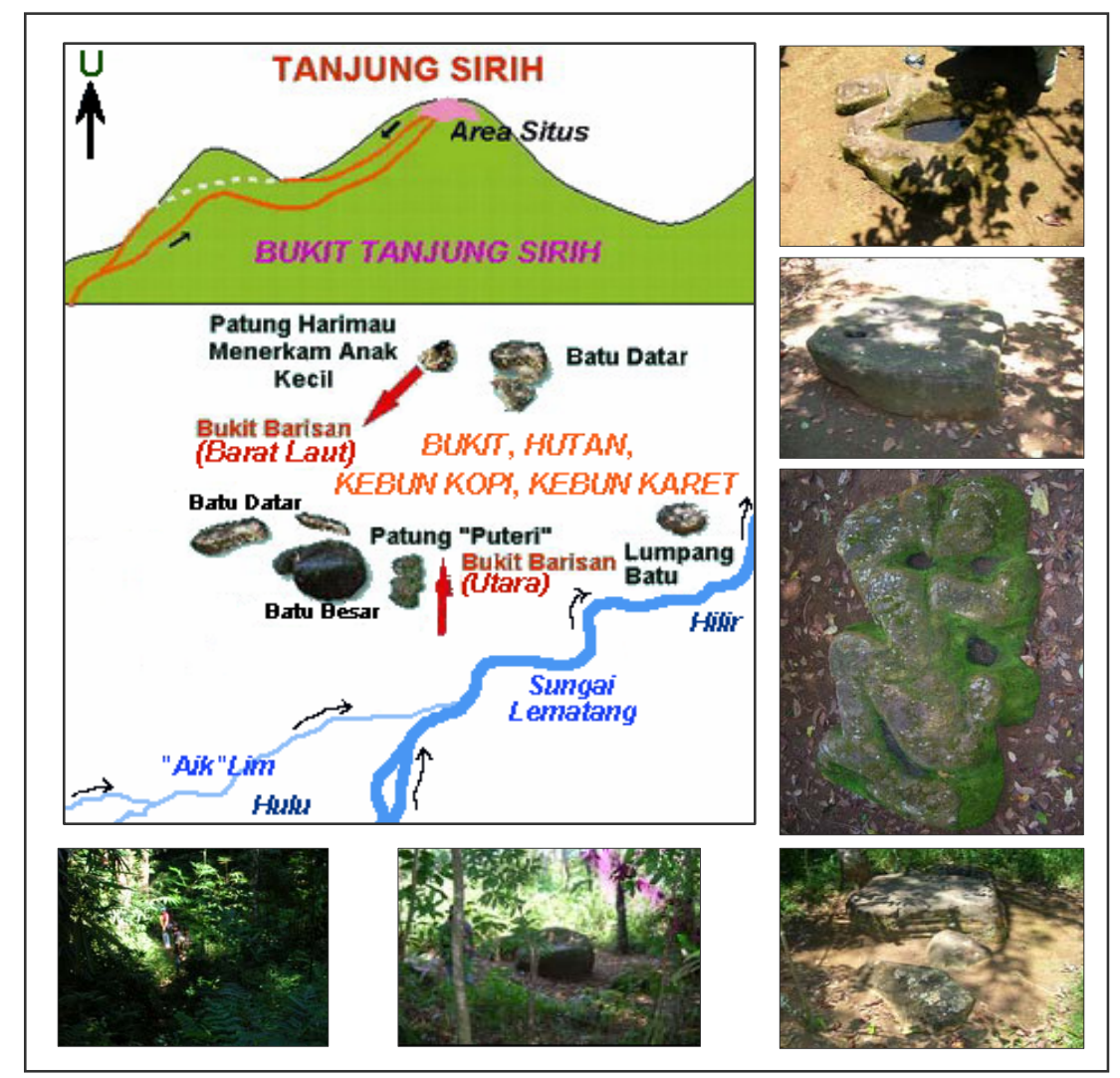

Gambar 5 Lingkungan situs Tanjung Sirih (Erwan Suryanegara, 2005/2006).

Bila memperhatikan secara keseluruhan wilayah sebaran situs-situs megalitik di bumi Pasemah, akan tampak adanya kepekaan tertentu pada masyarakat prasejarah Pasemah dalam memilih lokasi. Di lingkungan situs pilihan manusia 
prasejarah tersebut sudah tersedia secara alami bahan berupa bongkahan batubatu besar yang mempermudah mereka dalam pembuatan artifak batu monumental, bahkan secara umum lokasinya tidak jauh dari sungai atau sumber air lainnya.

\section{$5 \quad$ Ungkap Rupa Patung Megalitik di Pasemah}

Berdasarkan hasil peninjauan di lapangan terhadap 12 (dua belas) situs di dataran tinggi Pasemah dalam rangka penelitian ini, terbukti bahwa artifakartifak megalitik jenis patung memang memiliki jumlah terbanyak dibandingkan dengan artefak-artefak megalitik lainnya. Juga dari keduabelas situs megalitik yang dikunjungi itu, sesuai wujud perupaannya ternyata patung megalitik tersebut dapat dibedakan menjadi dua kategori atau kelompok.

Kategori dimaksud adalah berdasarkan perwujudan tokoh leluhur yang dijadikan media pemujaan berupa patung, yaitu: pertama, patung megalitik Pasemah yang menggambarkan satu wujud rupa atau sosok tunggal, dapat berupa seorang tokoh manusia atau hanya seekor binatang saja; Kedua, patung yang menggambarkan lebih dari satu wujud rupa atau sosok jamak, dapat berupa manusia dengan manusia atau manusia dengan binatang, sedangkan untuk objek binatang dengan binatang tidak terdapat di Pasemah.

\subsection{Patung Megalitik Berwujud Rupa Tunggal di Pasemah}

Di dataran tinggi Pasemah hanya beberapa situs yang memiliki patung megalitik bersosok tunggal, baik itu patung megalitik manusia maupun binatang. Di Lahat, keberadaan patung megalitik berwujud tunggal terdapat di situs Tanjung Sirih, namun sudah roboh dan sebagian besar terkubur, sehingga sulit diduga sebagai sosok tunggal atau jamak, Sinjar Bulan (kepala sudah hilang), dan Geramat. Sementara di Tebat Sibentur juga belum dapat dipastikan karena sebagian besar masih terkubur di dalam tanah. Di Pagaralam, patung megalitik bersosok tunggal hanya dijumpai di situs Belumai (Belumai III).

Dari patung-patung yang berobjek tunggal, jelas bahwa para pematung Pasemah di kala itu memang merupakan pematung batu yang handal dan berkualitas. Patung manusia membawa nekara di Belumai III termasuk salah satu dari artifak patung megalitik Pasemah yang kondisinya masih lengkap. Patung di Belumai III ini secara teknis juga tergolong sempurna, karena dilihat dari unsurunsur visualnya seperti karakter garis, volume, tekstur, warna, dan bentuk. 


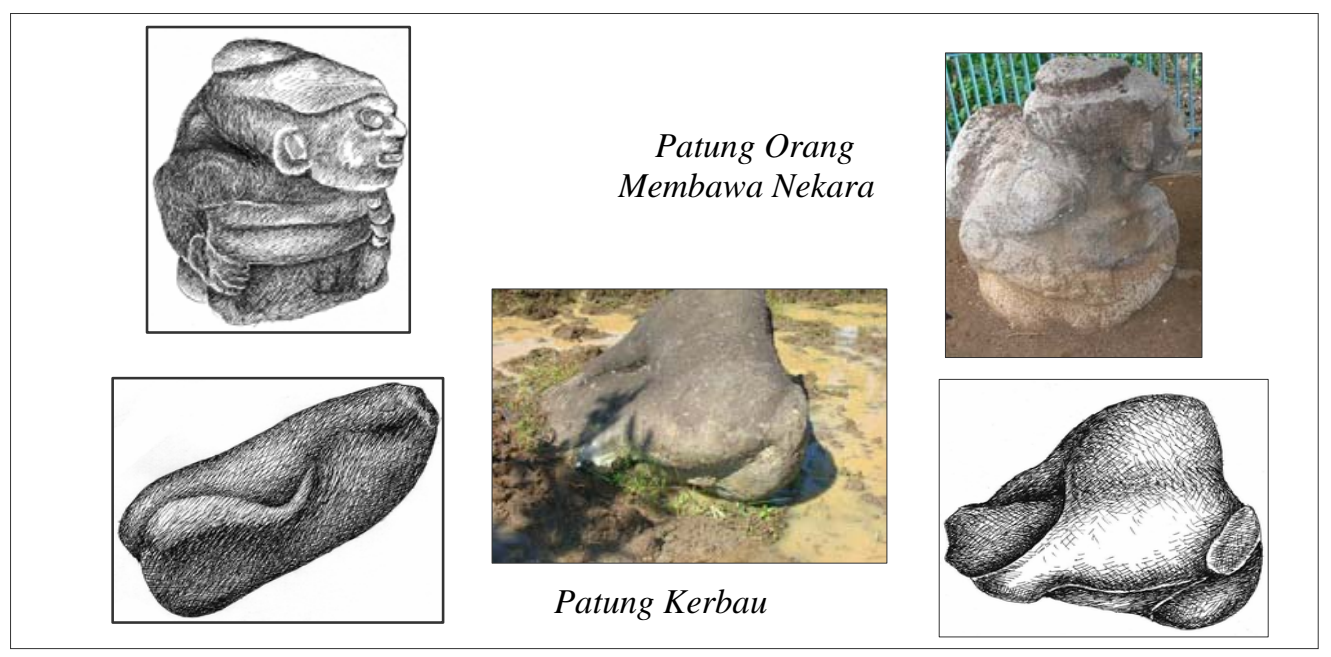

Gambar 6 Bentuk (ilustrasi) dan foto dua patung berwujud rupa tunggal di Pasemah (Erwan Suryanegara, 2006).

Proporsi kepala patung cenderung dibesarkan dan tampak sebagai pusat perhatian dari patung ini. Dengan pengolahan bentuk mata, hidung, bibir/mulut, rahang, sejenis penutup kepala, nekara, dan benda berbentuk lingkaran yang didukungnya. Sikap tubuh dari si tokoh yang dipahatkan sedemikian rupa, sebagai upaya untuk menyelaraskan bentuk patung manusia membawa nekara ini secara keseluruhan, sehingga tampilannya bersatu dan menarik. Artifak patung kerbau memperlihatkan bahwa pematungnya adalah seorang yang memiliki tingkat penguasaan bahan yang sangat baik, hal ini tampak dari posisi patung kerbau tersebut dipahatkan, khususnya dalam mensiasati bahan disaat memahat batu untuk membuat ekor kerbau.

Pada kedua patung megalitik Pasemah yang berwujud rupa tunggal tersebut di atas, berdasarkan perupaannya tampak cenderung realistik dengan memvisualkan seluruh bagian tubuhnya (kepala, badan, kaki, dan tangan), kecuali untuk patung kerbau yang bagian kepalanya memang sudah patah (hilang). Namun bila dilihat berdasarkan jenis kelaminnya, kedua patung itu tidak memperlihatkan adanya ciri-ciri genitalnya. Ukuran kedua patung ini dapat dikatakan relatif berukuran kecil, bila dibandingkan dengan ukuran patung-patung megalitik yang terdapat di Pasemah pada umumnya.

\subsection{Patung Megalitik Berwujud Rupa Jamak di Pasemah}

Patung megalitik di Pasemah mayoritas memvisualkan wujud rupa jamak, baik itu patung manusia dengan manusia maupun manusia dengan binatang. Dari patung yang diteliti hanya satu yang memperlihatkan ciri genitalnya, yaitu 
patung 'ibu dengan anaknya' di Tinggi Hari II. Sementara patung yang memvisualkan binatang tidak ditemukan di dataran tinggi Pasemah, tetapi di daerah ini terdapat patung yang jumlah wujudnya lebih dari dua.

Patung megalitik di Pasemah berbeda dengan patung megalitik lainnya, sehinggga tidak dapat dijadikan objek pembanding bagi patung megalitik Nusantara. Pendapat ini diungkapkan oleh Haris Sukendar sebagai seorang pakar megalitik Indonesia, yang sepakat akan hal itu bahkan menambahkan, bahwa patung megalitik di Pasemah itu memiliki keunikannya yang "tersendiri" dan tidak dimiliki oleh patung megalitik lainnya yang sezaman. Lebih lanjut menurut Haris, di wilayah lain patung megalitik yang sezaman masih tergolong "arca menhir", dicirikan dalam hal perwujudannya bersifat statis-frontal dan masih sederhana (cenderung lebih mengutamakan kepala), atau belum selengkap seperti perupaan sosok tubuh pada patung megalitik di Pasemah.

Sebagaimana halnya patung berwujud rupa tunggal, pada patung yang berwujud rupa jamakpun visualisasinya cenderung realistik, dengan menampilkan seluruh anggota badan, baik untuk sosok manusia maupun binatang. Bila memperhatikan bentuk (form) dari patung-patung megalitik di Pasemah, terlihat kemampuan dari para pematungnya dalam memvisualkan bentuknya seolah wajah, lengan, bahu, dan sebagainya dari sosok itu berdaging. Demikian pula dalam perupaan atribut yang diterapkan pada masing-masing patung megalitik di Pasemah, dapat dirasakan seolah gelang itu adalah lempengan logam, kalung itu berupa untaian manik-manik yang terbuat dari bahan batu permata, tulang, dan lain sebagainya.

Kelengkapan anggota badan dari sosok yang dijadikan objek patung megalitik di Pasemah ini, terlihat pada seluruh perupaan patung-patung megalitik yang telah diteliti, walaupun kondisinya saat ini sudah mulai rusak, patah atau hilang terutama bagian kepala patung. Pematung-pematung di bumi Pasemah saat itu tampak berbeda dengan pematung megalitik sezamannya yang bergaya Polynesia, yang dicirikan dengan kepala dan atau badan dari sosok tokoh yang dipatungkan. Kelengkapan anggota badan tersebut menunjukkan bahwa perupaan wujud (shape) patung megalitik Pasemah yang memang dinamis.

Bila dibandingkan antara satu situs dengan situs lainnya, terlihat jelas bahwa patung megalitik di Pasemah tidak mengenal adanya pengulangan bentuk. Dengan kata lain dapat disimpulkan bahwa patung-patung megalitik tersebut secara visual selalu berbeda, baik untuk sosok manusia juga binatang. Perbedaan itu tampak pada ukuran, perupaan wajah, sikap tubuh (posisi badan, kepala, kaki, dan tangan). Kesamaan yang ada hanya pada tema, gaya perupaan, tidak berdiri tegak, wajah menengadah, gelang logam, gajah, kerbau, ular, dan lain-lain. 
Berdasarkan analisis ungkap rupa, patung megalitik di Pasemah lebih dominan menggambarkan hubungan mesra atau keinginan berdamai antara manusia dengan binatang, termasuk patung "Macan Kawin" dan orang berkelahi/dibelit ular (representasi dari masyarakat dengan pola budaya berladang). Dari kedua puluh empat patung hasil survey, hanya terdapat tiga buah patung yang bertema perkelahian, oleh masyarakat pemburu kerap dimitoskan sebagai konsep "kematian menuju kehidupan".

Memperhatikan ciri-ciri anatomis, khusus untuk perupaan wajah tokoh atau sosok yang dipatungkan di Pasemah, baik yang berobjek tunggal maupun jamak terutama yang terdapat di situs-situs Kota Pagaralam, dimana cenderung memiliki ciri austronesoid. Ciri-ciri anatomis austronesoid yang tampak itu adalah bermata bulat (melotot), bibir tebal, hidung besar tidak mancung, dan karakter rahang yang lebih menonjol.

Pendapat bahwa adanya ciri-ciri austronesoid ini juga sejalan dengan apa yang dikemukakan oleh para peneliti sebelumnya, bahwa diperkirakan manusia pendukung budaya megalitik di bumi Pasemah adalah dari ras "austromelanesoid", yaitu ras austronesoid yang bercampur dengan ras melanesoid. Pendapat para ahli tersebut didasarkan pada teori 'persebaran' dan juga melihat hubungan antara bentuk orang yang dipatungkan dengan atributatribut yang dipahatkan pada tokoh manusia yang dipatungkan.

Ukuran patung megalitik di Lahat umumnya besar-besar, diameternya ada yang mencapai $527 \mathrm{~cm}$ dan tinggi $250 \mathrm{~cm}$, relatif lebih besar dibanding dengan di Pagaralam, kecuali patung di Belumai I yang lingkarannya $416 \mathrm{~cm}$ dan panjang $345 \mathrm{~cm}$. Ukuran patung terkecil ada di Tegur Wangi, Pagaralam dengan lingkaran $330 \mathrm{~cm}$ dan tinggi $100 \mathrm{~cm}$. Berdasarkan identifikasi objek patung megalitik di Pasemah khususnya jenis binatang, secara umum yang dibuat patungnya adalah binatang yang hidup di Sumatra: kerbau, gajah, buaya, babi hutan, ular, harimau, dan orang utan. Perwujudan sosok manusia dan binatang secara bersama pada sebuah patung, jelas nunjukkan bahwa pendukung tradisi megalitik di Pasemah adalah suatu masyarakat dengan budaya agraris (kebun, ladang, atau sawah).

Dari keduabelas situs Pasemah yang dikunjungi, keberadaan patung megalitik tampaknya juga selalu memiliki hubungan dengan artifak-artifak megalitik lainnya, bahkan ketika di lapangan terlihat adanya satu kecenderungan bahwa patung megalitik di Pasemah, keberadaannya selalu bersama atau tidak berjauhan dari artifak megalitik yang berupa batu datar dan atau lumpang batu. Lumpang batu tersebut, ada yang memiliki lubang satu, dua, dan empat, kecenderungan tadi apakah merupakan suatu pola yang memang dimiliki oleh tradisi megalitik di Pasemah, masih memerlukan penelitian lanjutan. 

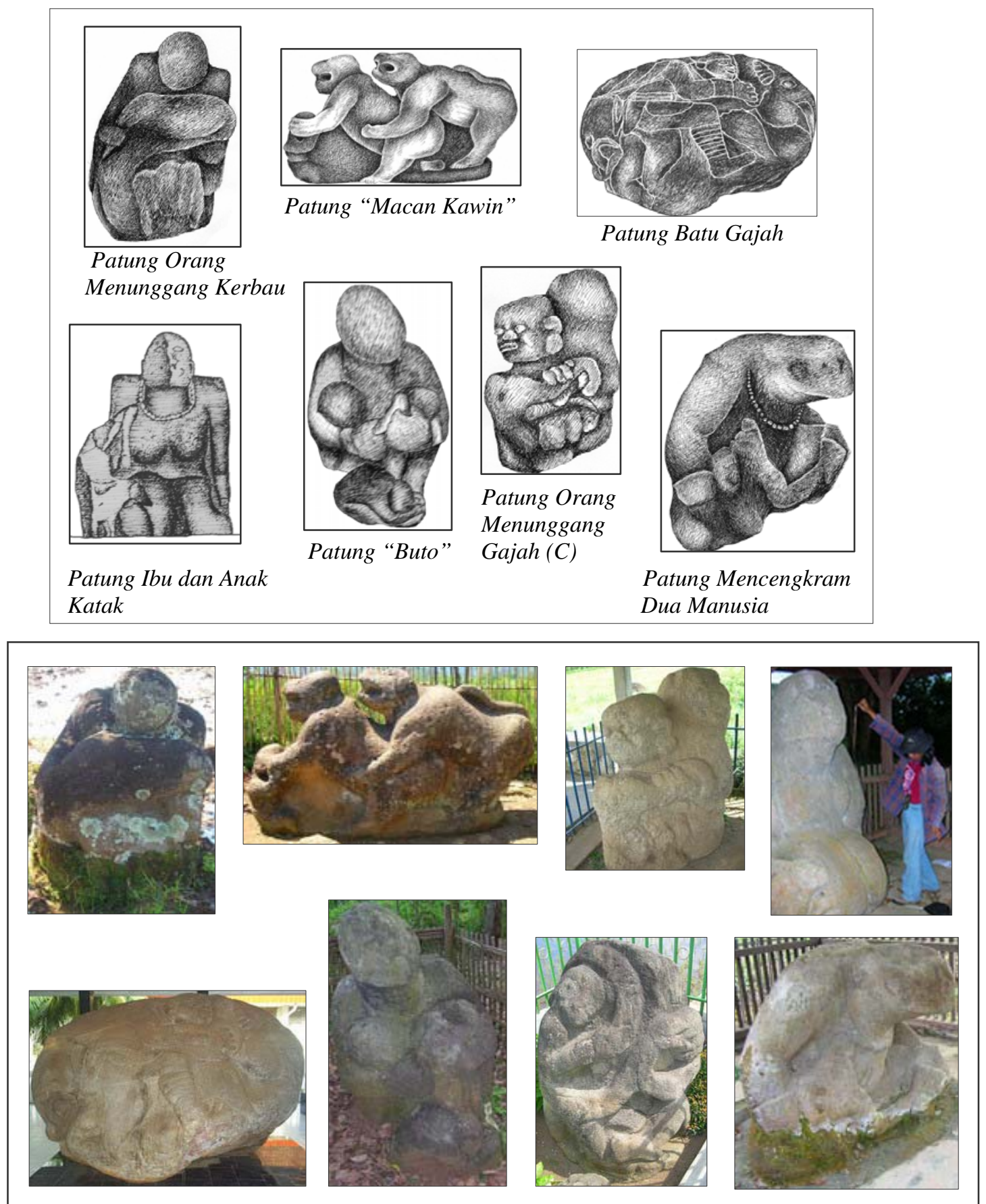

Gambar 7 Beberapa bentuk (ilustrasi) patung-patung berwujud rupa jamak di Pasemah. 
Tabel 1 Ungkap rupa dua patung megalitik di Pasemah.

\begin{tabular}{|c|c|c|c|c|}
\hline No. & $\begin{array}{l}\text { Nama Situs } \\
\text { dan Patung }\end{array}$ & $\begin{array}{c}\text { Struktur } \\
\text { Bentuk/Sosok }\end{array}$ & Data Fisik & Deskripsi \\
\hline 1. & $\begin{array}{l}\text { Belumai III } \\
\text { Patung } \\
\text { Orang } \\
\text { Membawa } \\
\text { Nekara }\end{array}$ & $\begin{array}{l}\text { Orang } \\
\text { Nekara } \\
\text { Benda } \\
\text { berbentuk } \\
\text { lingkaran }\end{array}$ & $\begin{array}{l}\text { - Batu andesit putih } \\
\text { keabu-abuan. } \\
\text { - Orientasi Bukit } \\
\text { Barisan (Barat } \\
\text { Laut). } \\
\text { - Berdiri dengan kaki } \\
\text { ditekuk. } \\
\text { - Tinggi = } 134 \mathrm{Cm} \text {. } \\
\text { - Lingkr.= } 383 \mathrm{Cm} \text {. } \\
\text { - Mata melotot. } \\
\text { - Bibir tebal. } \\
\text { - Atribut: Penutup } \\
\text { kepala, nekara, } \\
\text { gelang tangan, } \\
\text { benda berbentuk } \\
\text { lingkaran dgn } \\
\text { ketebalan } \pm 20 \mathrm{~cm} . \\
\text { - Simbol lingkaran di } \\
\text { persendian lengan. } \\
\text { - Tanpa ciri genital. }\end{array}$ & $\begin{array}{l}\text { - Visual bersifat } \\
\text { dinamis-piktorial } \\
\text { cenderung realistik. } \\
\text { - Representasi } \\
\text { perjalanan arwah } \\
\text { (sesuai dengan fungsi } \\
\text { nekara). } \\
\text { - Si tokoh tidak sedang } \\
\text { berjalan, karena } \\
\text { wajahnya menoleh ke } \\
\text { kiri dan cenderung } \\
\text { menengadah. } \\
\text { - Nekara sebagai benda } \\
\text { sakral diperlakukan } \\
\text { istimewa, terlihat dari } \\
\text { cara si tokoh } \\
\text { membawanya, yang } \\
\text { cenderung dipapah. }\end{array}$ \\
\hline 2. & \begin{tabular}{|l} 
Tinggihari I \\
Tokoh sejenis \\
amphibi (katak) \\
mencengkram \\
dua manusia
\end{tabular} & & $\begin{array}{l}\text { - Batu andesit putih } \\
\text { keabu-abuan. } \\
\text { - Orientasi Bukit } \\
\text { (Tenggara) } \\
\text { - Katak berdiri } \\
\text { dengan dua kaki } \\
\text { ditekuk, badan } \\
\text { condong ke depan, } \\
\text { dan kepala hilang. } \\
\text { - Tinggi = } 135 \mathrm{Cm} \text {. } \\
\text { - Lingkr. = 429 Cm. } \\
\text { - Atribut: Kalung dan } \\
\text { gelang tangan dan } \\
\text { kaki. } \\
\text { - Tanpa ciri genital. }\end{array}$ & $\begin{array}{l}\text { - Visual bersifat } \\
\text { dinamis-piktorial } \\
\text { cenderung realistik. } \\
\text { - Representasi ritual } \\
\text { mistis (upacara } \\
\text { persembahan/ } \\
\text { permohonan). } \\
\text { - Dua orang kepalanya } \\
\text { hilang, orang di sisi } \\
\text { kanan memegang } \\
\text { lengan yang di sisi kiri. }\end{array}$ \\
\hline
\end{tabular}




\subsection{Kandungan Makna Patung Megalitik di Pasemah}

Sesuai dengan pola pikir mistis di masa itu, patung-patung megalitik seperti halnya di Pasemah diyakini merupakan media penghubung (mendekatkan diri) dengan arwah leluhur atau nenek moyangnya (baca: [2],[10]). Religi pada Masyarakat Prasejarah Indonesia). Dalam kosmologi masyarakat prasejarah, melalui suatu upacara dengan ritus-ritus tertentu yang dilakukan itu sangat diyakini, bahwa mereka akan mengalami dan mencapai kesatuan (trance) dengan arwah leluhur atau tokoh nenek moyangnya yang dianggap mengayomi dan menguasai alam semesta.

Dari segi bentuk patung-patung megalitik di bumi Pasemah, terdapat kecenderungan untuk membesarkan badan atau "tambun". Sangat tidak tepat kalau para seniman atau pematung di dataran tinggi Pasemah kala itu, bahwa mereka telah membuat patung-patung yang tidak proporsional, karena berdasarkan konsep mistisisme justru proporsi seperti pada patung-patung megalitik itulah yang seharusnya dipahatkan atau dibuat. Patung tokoh manusia yang dipahatkan bertubuh atau berlengan besar, proporsi dibesarkan tersebut tentu disesuaikan dengan konsep atau pola pikir mistis, yakni untuk memvisualkan sesuatu yang bermakna bahwa arwah tokoh leluhur atau nenek moyang mereka itu maha menguasai, maha besar, maha perkasa, maha kuat, maha melindungi, dan lain sebagainya (baca: [14]).

Perwujudan bentuk dari patung-patung megalitik yang terdapat di bumi Pasemah, tidak terpaku lagi kepada komposisi bentuk yang simetris-frontal. Dari situs yang diteliti semua patung cenderung memiliki komposisi bentuk asimetri. Menurut beberapa peneliti sebelumnya bahwa posisi badan dan kepala patung yang relatif condong ke depan itu merupakan sikap membungkuk. Bila dicermati lebih seksama lagi sesungguhnya sikap tersebut bukan membungkuk, karena wajahnya tidak menunduk tetapi cenderung menengadah, dan ini merupakan salah satu dari ciri khas patung megalitik Pasemah.

Masih sehubungan dengan sikap tubuh dari tokoh-tokoh yang dipatungkan ini, pada umumnya patung megalitik Pasemah selalu dengan sikap kaki ditekuk atau dilipat (tidak berdiri tegak), bahkan banyak juga patung-patung megalitik di Pasemah yang sikapnya dalam posisi duduk bersimpuh di atas kedua kaki, dan ada pula yang duduk sambil memeluk lutut. Sikap atau perupaan patung yang demikian, secara teknis tentunya terkait erat dengan kondisi volume bahan dasar dari material batu yang ada dan tersedia di Pasemah. Di wilayah ini memang sulit untuk menemukan bongkahan batu monolit, dengan volume (terutama ukuran tingginya) yang memadai untuk dapat dijadikan patung dengan sikap si tokohnya yang berdiri tegak. 


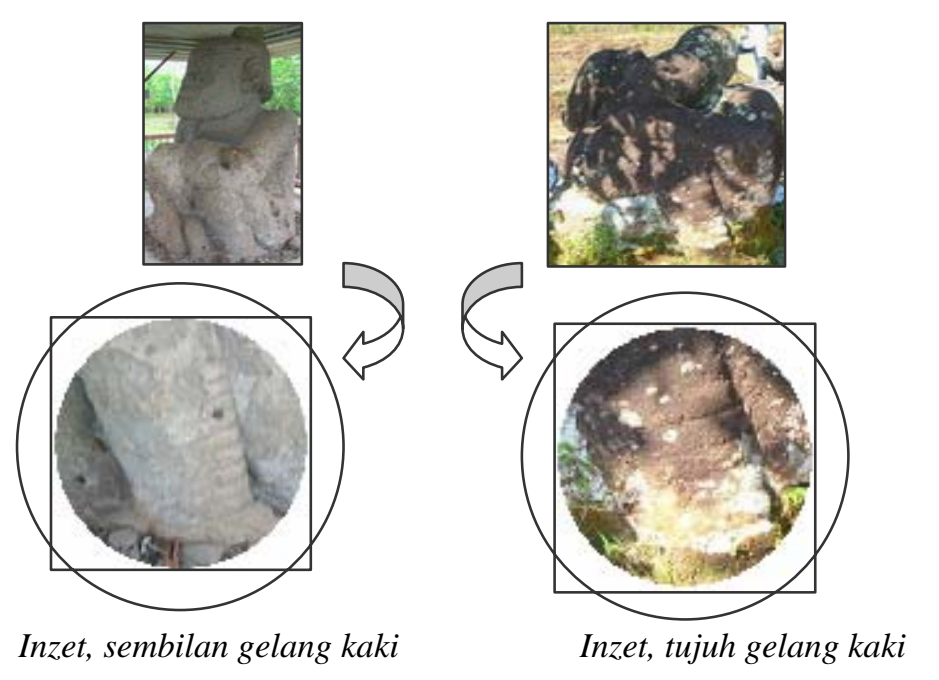

Gambar 8 Varian atribut gelang kaki menunjukkan fungsi patung megalitik sebagai monumen lambang kekuasaan si tokoh/leluhur.

Demikian pula dengan perupaan atribut yang selalu ikut dipahatkan pada patung-patung megalitik di Pasemah, khususnya pada patung yang objek utamanya manusia. Atribut baju yang tampak membungkus ketat tubuh si tokoh, dengan dilengkapi sebilah belati besar atau pedang, tentu dapat dimaknai bahwa tokoh itu adalah seorang prajurit atau panglima perang yang berjiwa kesatria. Atribut kalung yang berbentuk unik, tentu untuk menggambarkan bahwa si tokoh bukanlah orang biasa. Begitu pula dengan atribut gelang kaki, yang memiliki jumlah bilangan bervariasi dari satu hingga sembilan (patung "Imam" bergelang kaki sembilan). Varian gelang kaki ini tampaknya ingin menandai bahwa si tokoh adalah penguasa, bagaikan satu, empat, lima, tujuh, atau sembilan aliran sungai. Sungai dimaksud tentunya adalah sungai yang berada di wilayah teritorial Batang Hari Sembilan, meliputi daerah-daerah di Sumatra bagian Selatan yakni: Jambi, Bengkulu, Sumatra Selatan, dan Lampung dengan sembilan buah sungainya.

\subsection{Simbol Pada Patung Megalitik Pasemah}

Agar tidak terjadi kerancuan pemahaman dalam pembahasan seputar simbol ini, perlu dibedakan antara pengertian simbol sebagai "lambang” yang berbentuk dan bersifat khusus (konvensional), dengan "perlambangan menjadi lambang, dan atau mengenai lambang" (simbolik = icon). Sehubungan dengan patungpatung megalitik di Pasemah ini, maka yang dimaksud simbol adalah lambang yang memiliki bentuk dan bersifat khusus, sementara sosok hewan, si tokoh 
manusia termasuk atributnya adalah perlambangan, menjadi lambang, dan atau simbolik.

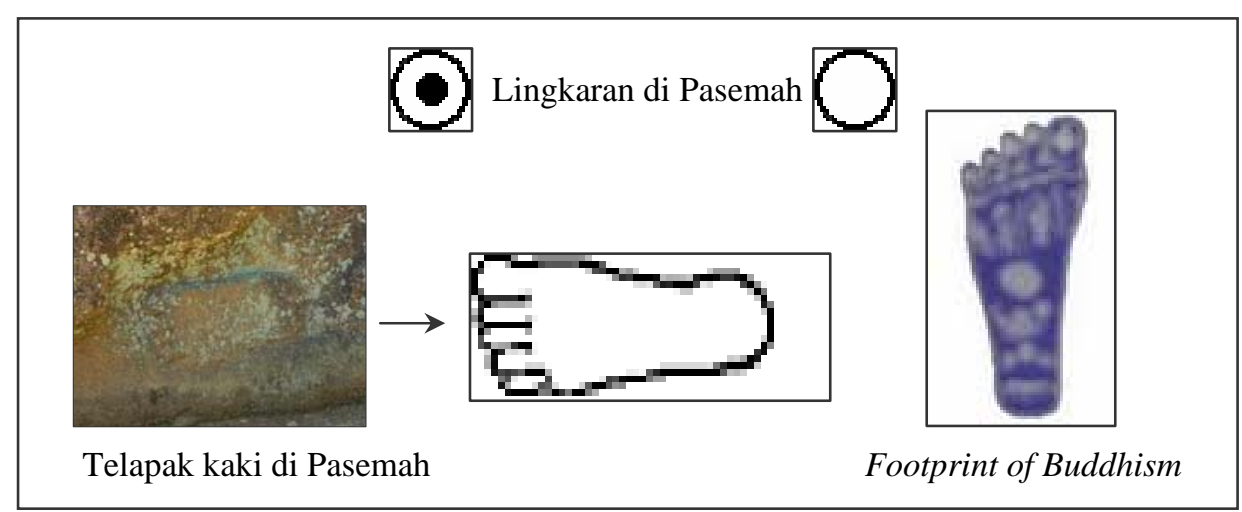

Gambar 9 Simbol lingkaran dan telapak kaki kiri (Sumber: Buku The complete Dictonary of Symbols \& foto penelitian, Agustus '05).

Bentuk simbol khusus yang pertama, berupa lingkaran dengan bulatan di tengahnya, simbol ini terdapat di beberapa patung megalitik Pasemah, bahkan pada sebuah patung simbol tersebut berjumlah lebih dari satu. Jenis simbol yang kedua adalah berupa tiga buah lingkaran yang berdekatan masing-masing berdiameter \pm 15 (lima belas) cm, dan simbol ini hanya terdapat pada patung 'orang menunggang kerbau' di situs Belumai I, yang penempatannya dipahatkan pada bagian atas kepala si tokoh. Jenis yang ketiga adalah menyerupai sebuah telapak kaki kiri manusia (ikon, indeks, simbol). Jenis simbol ini juga merupakan satu-satunya dan hanya terdapat pada patung 'macan kawin' pada situs Pagaralam Pagar Gunung. Simbol telapak kaki kiri tersebut dipahatkan di sisi kiri bagian bawah patung Macan Kawin ini, yaitu diantara kaki kedua ekor harimau tersebut.

Untuk jenis simbol pertama yang berupa lingkaran dengan bulatan di tengahnya atau juga jenis kedua yang hanya berupa suatu lingkaran biasa, secara bentuk keduanya memiliki kesamaan yakni berupa lingkaran (cyrcle). Sehubungan dengan simbol yang berbentuk cyrcles ini, sebagaimana diketahui dalam berbagai kepercayaan juga kebudayaan di banyak tempat memiliki makna antara lain, sebagai poros atau pusat (center), gerak memusat (melingkar), pencerahan (pada simbol Kristiani), keutamaan (pada simbol Hindu dan Budha), lubang - pusar perut - susu (simbol suku Asmat), matahari (sumber energi kehidupan), bulan purnama (iconography), dan masih banyak lagi maknanya.

Didier Colin dalam Dictionary of Symbols, Myths, and Legends, Hachette (2000), hlm. 100-103, menguraikan makna lingkaran menurut peradaban kuno, 
langit adalah sebuah prinsip feminin yang biasanya dilambangkan oleh sebuah lingkaran dan bumi sebagai prinsip maskulin dilambangkan dengan bentuk persegi. Nenek moyang kita membayangkan tanah yang mereka tinggali adalah bagian dari sebuah dunia yang datar, disokong oleh sebuah bola, dengan langit di atas dan di bawah. Dalam pandangan mereka, siang dan malam, ditentukan oleh pergerakan planet-planet, yang bergerak terus-menerus dalam rotasi. Simbol lingkaran memiliki sebuah makna khusus yang berkaitan dengan keutuhan dunia.

Dari uraian di atas jelas bahwa simbol lingkaran dan atau lingkaran dengan bulatan kecil di tengahnya seperti yang ada di Pasemah, adalah berkaitan dengan prinsip feminin langit dan prinsip maskulin bumi. Karena persegi bumi selalu ditempatkan di tengah lingkaran langit, keduanya memiliki pusat yang sama, karena itu konsep lingkaran selalu diikuti konsep pusat atau titik sentral, yang juga bersifat melingkar sebagaimana simbol lingkaran di Pasemah yang selalu ditempatkan di persendian dan atau di kepala. Sementara untuk jenis simbol yang ketiga, seperti yang disebutkan di dalam buku Kumpulan Makna Simbol [9], dikatakan: "Images of feet sometimes appear in iconography as signs that indicate contact between the earth and a divinity. In Buddhism, the spiritual superiority of the Buddha is depicted by the soles of his feet, bearing seven symbols of his divine wisdom ..."

Selain berkaitan dengan kepercayaan dalam budaya mistis masyarakat Pasemah kala itu, sesungguhnya simbol telapak kaki dapat bermakna pula sebagai penanda kekuasaan atas suatu wilayah (teritorial) tertentu, hal ini cukup beralasan kuat karena patung tersebut di dalam wujud utamanya adalah menggunakan bentuk harimau yang bermakna 'penguasa hutan'.

\subsection{Arah Hadap Patung Megalitik Pasemah}

Di setiap situs megalitik Pasemah yang dijadikan lokasi objek penelitian, semua artifak menghadap ke arah ke bukit, gunung, sungai, anak sungai, tebat, atau sumber air. Orientasi atau arah hadap tersebut menjadi pola tetap dari setiap artifak megalitik di Pasemah. Kenyataan ini jelas berkaitan erat dengan kondisi topografi dataran tinggi Pasemah yang bergelombang dengan gunung dan bukitbukitnya, serta dataran tinggi Pasemah yang masih merupakan bagian atau kelanjutan dari Bukit Barisan Sumatra.

Arah hadap ke air, bukit, dan atau gunung itu tentunya sesuai pula dengan konsep atau pola pikir budaya mistis suatu masyarakat prasejarah, yang meyakini bahwa air, bukit, dan gunung merupakan tempat suci atau dunia bersih dan dunia atas sebagai tempat bersemayamnya arwah leluhur. Dari keduabelas situs yang dijadikan lokasi survei, ada beberapa situs yang memang 
memiliki lokasi atau berada di puncak perbukitan, yaitu: Situs Pulau Panggung di Tanjung Sirih dan situs komplek Tinggi Hari I, II, dan III.

Mengingat wilayah bumi Pasemah yang memang masih berada di dalam jalur Bukit Barisan, tampak kondisi alam yang berbukit-bukit itu sangat disadari oleh pematung-pematung Pasemah di masa lalu itu. Berdasarkan fakta di lapangan kemanapun patung-patung megalitik itu diarah hadapkan, patung-patung tersebut cenderung tetap akan mengarah ke Bukit Barisan. Memperhatikan arah hadap patung-patung megalitik di Pasemah, menjadi jelas bahwa dalam budaya prasejarah, konsep tentang arah hadap suatu artifak memang sangatlah dipentingkan, karena dengan penempatan arah hadap yang benar (sesuai konsep budaya mistis) diharapkan dan diyakini akan memberikan kebaikan, keamanan, dan atau kesejahteraan, baik kepada mereka yang masih hidup begitu juga bagi arwah leluhurnya.

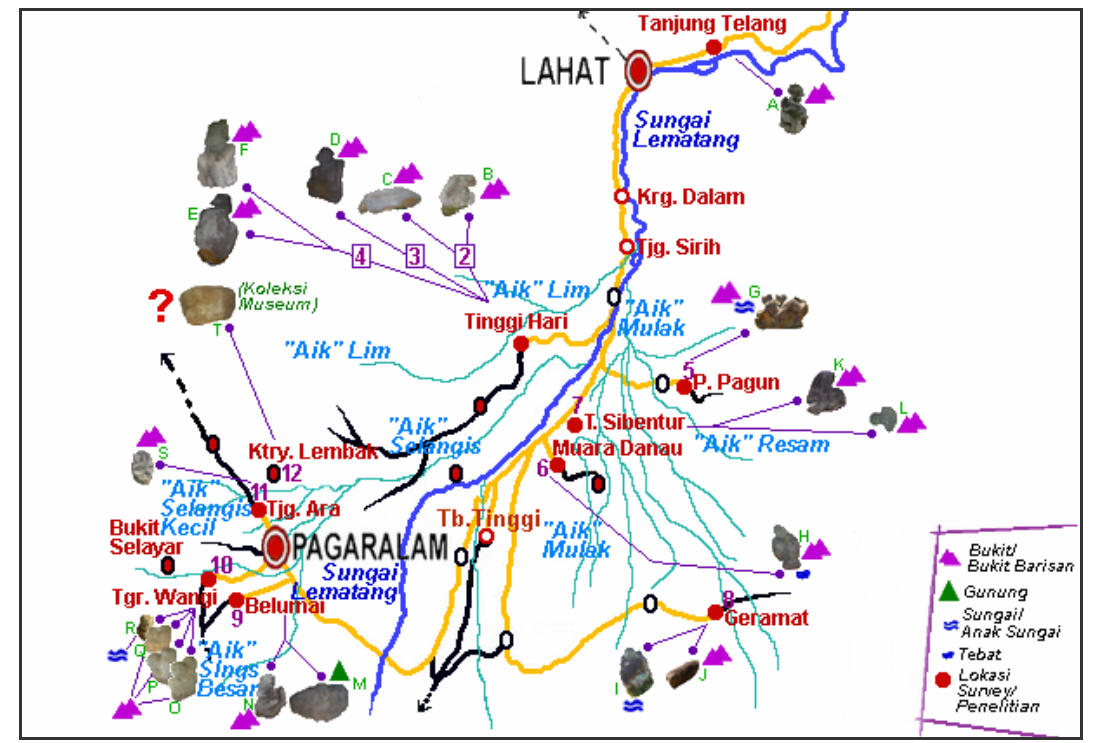

Gambar 10 Arah hadap patung-patung megalitik di Pasemah yang diteliti.

Berkenaan dengan arah hadap suatu patung megalitik itu ke gunung atau ke bukit tampaknya bukan menjadi persoalan yang begitu dipentingkan, karena dari keseluruhan arah hadap patung-patung megalitik di Pasemah, hanya patung orang menunggang kerbau di Belumai I yang menghadap ke gunung Dempo. Sementara pada patung 'macan kawin' di Pagaralam Pagun, patung Buto di Muara Danau, Orang Menunggang Kerbau di Geramat, dan satu dari empat patung 'orang menunggang gajah' di Tegur Wangi adalah patung-patung 
megalitik Pasemah yang memiliki arah hadap ke air (sungai/anak sungai atau tebat).

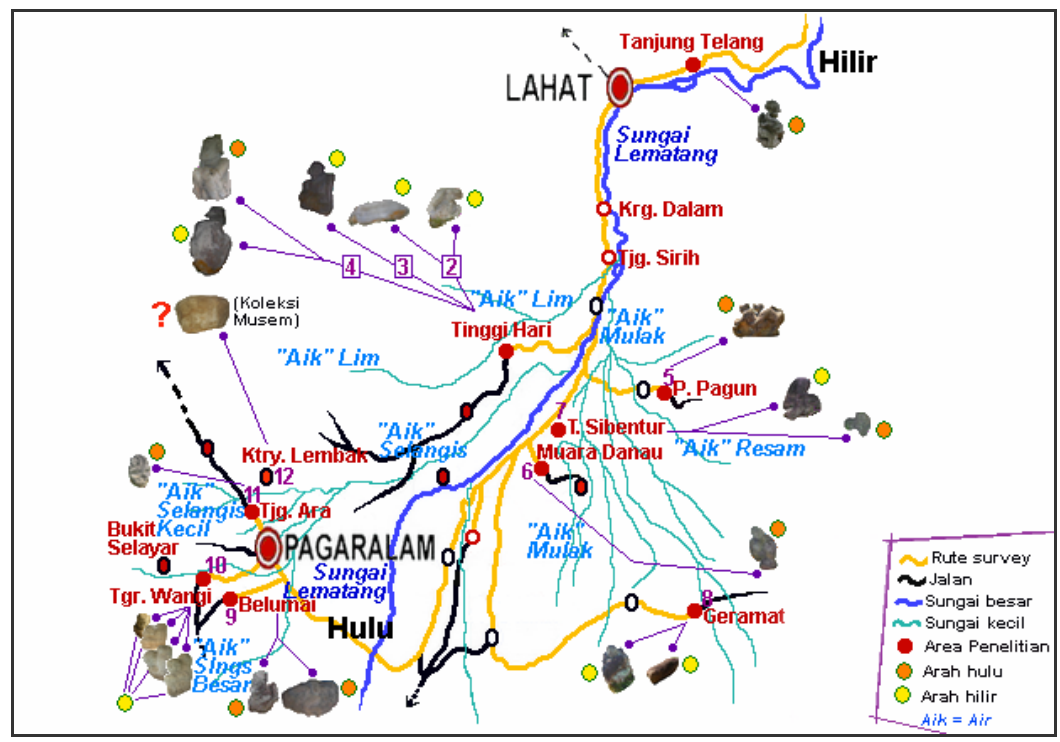

Gambar 11 Pola penempatan arah hulu - hilir patung megalitik di Pasemah.

\subsection{Peran dan Fungsi Patung Megalitik Pasemah}

Dari keduabelas situs yang dikunjungi, hanya situs Karang Dalam yang tidak memiliki patung megalitik. Perbandingan satu berbanding sebelas situs ini dan juga keberadaan patung selalu bersama-sama dengan artifak megalitik yang lain. Hal itu merupakan satu bukti yang mengisyaratkan bahwa patung megalitik di Pasemah memiliki peranan penting dalam suatu upacara ritual ketika itu. Dengan demikian boleh dikatakan bahwa pada setiap penyelenggaraan upacara dan ritual mistis di Pasemah di masa itu, patung megalitik selalu berperan dan digunakan sebagai salah satu media utama dalam pelaksanaan upacara dan ritus-ritus pemujaan terhadap arwah nenek moyang.

Patung megalitik Pasemah merupakan monumen yang dinilai 'sudah tidak dipakai lagi' atau dead monuments, karena secara arkeologis patung-patung tersebut tidak dapat memberikan data mengapa ia dibuat, untuk apa ia dibuat, dan bagaimana membuatnya. Namun para peneliti sebelumnya, baik peneliti asing maupun peneliti Indonesia, memiliki pandangan yang sama bahwa bila dikaitkan dengan kebutuhan manusia di masa itu, patung-patung megalitik di Pasemah pada dasarnya hanya mengacu kepada aspek religius dan dibuat untuk tujuan pemujaan terhadap arwah nenek moyang. 
Keberadaan patung megalitik Pasemah seperti yang disebutkan di atas, mungkin sekali awalnya justru datang dari keinginan si tokoh atau pemimpin itu sendiri, yang dengan kekuasaannya berkeinginan untuk menunjukkan dan sekaligus melanggengkan pengaruh kekuasaannya, melalui pembuatan monumen patung merupakan perlambangan tentang dirinya. Kemudian pada generasi-generasi berikutnya patung megalitik tersebut menjadi sarana pemujaan kepada arwah leluhur.

Jumlah-jumlah hitungan gelang kaki yang dipahatkan pada sejumlah patung megalitik di Pasemah, memiliki makna simbolik, yaitu untuk menggambarkan luasnya wilayah atau pengaruh kekuasaan seorang tokoh yang dipatungkan tersebut. Tokoh yang bergelang kaki sebuah atau satu, merupakan perlambangan dari pengaruh kekuasaannya meliputi satu aliran sungai. Demikian pula patung-patung yang memiliki gelang kaki empat, lima, dan jumlah lainnya. Sebagai contoh pada patung "Imam”, adalah salah satu patung megalitik di Tinggi Hari III yang dipahatkan memiliki sembilan buah gelang kaki, hitungan sembilan merupakan jumlah tertinggi untuk gelang kaki yang dipahatkan pada patung-patung megalitik di bumi Pasemah.

\section{Simpulan}

Perwujudan bentuk patung megalitik di bumi Pasemah memiliki ciri khas, yakni besifat dinamis-piktorial dan cenderung realistik, baik untuk sosok orang yang menggambarkan tipe ras austronesoid maupun binatang. Patung megalitik Pasemah merepresentasikan arwah nenek moyang, selalu dalam sikap tubuh cenderung condong ke depan, dengan kepala atau wajah juga cenderung menengadah, baik ke arah depan, menoleh ke samping, ataupun ke belakang. Visualisasi demikian itu sebagai upaya guna memberikan gambaran kewibawaan dan keagungan kepada sang tokoh (nenek moyang) yang dijadikan pujaan.

Patung megalitik Pasemah dibuat sebagai salah satu media penting dalam pelaksanaan upacara dan ritual untuk pemujaan arwah nenek moyang, serta merupakan kebutuhan pokok religius masyarakat prasejarah yang bersifat mistis. Budaya megalitik Pasemah merupakan satu rangkaian dengan tradisi megalitik Indonesia lainnya, terutama yang ada di Jambi, Bengkulu, dan Lampung.

Kecenderungan kaki dari sosok tokoh orang yang dipatungkan pada patungpatung megalitik di Pasemah juga selalu dengan sikap ditekuk, dan atau dilipat, tidak terdapat patung megalitik di Pasemah dengan sikap kaki yang terbentang lurus atau berdiri tegak. Beberapa patung megalitik Pasemah ada yang sikapnya 
dalam posisi duduk bersimpuh di atas kedua kaki, dan ada pula patung yang duduk dengan lutut berdiri sejajar dada.

Para pematung Pasemah pada masa itu adalah "seniman" yang memiliki rasa atau kepekaan bentuk (form) sangat baik, hal ini terlihat dari perupaan pada karya-karya patung yang mereka buat dan ditemukan di dataran tinggi Pasemah. Di lapangan kondisi patung-patung tersebut sudah banyak mengalami pelapukan dimakan usia, namun dari perupaan terutama keadaan permukaan (tekstur) yang tersisa, masih dapat dirasakan bagaimana keadaan kulit terutama pada sosok beberapa binatang seperti yang dipatungkan di Pasemah.

Masyarakat prasejarah Pasemah di masa itu adalah masyarakat pendukung budaya atau tradisi megalitik. Sebagaimana halnya dalam suatu budaya megalitik, maka masyarakat prasejarah di bumi Pasemah memiliki keyakinan atau kepercayaan terhadap arwah nenek moyangnya. Menurut kepercayaan ini bahwa arwah nenek moyang tersebut bersemayam di tempat-tempat suci atau "dunia atas”, yaitu di puncak-puncak gunung dan atau bukit-bukit yang tinggi.

Patung megalitik di Pasemah umumnya selalu diarahhadapkan ke bukit atau gunung yang ada. Untuk situs Tanjung Sirih dan komplek situs Tinggi Hari, bahkan letaknya memang sudah berada di puncak bukit. Arah hadap patung megalitik Pasemah dan kedua situs tersebut yang berada di puncak bukit, membuktikan adanya hubungan erat dengan kepercayaan mistis masyarakat pendukungnya, bahwa arwah nenek moyang mereka memang bersemayam di puncak bukit atau gunung.

Terdapat kecenderungan pada patung megalitik Pasemah untuk selalu bersama atau berdekatan dengan artifak megalitik lain khususnya lumpang batu dan batu datar, maka patung megalitik Pasemah juga termasuk menhir atau batu tegak lainnya yang bersifat vertikal, merupakan perlambangan dari atau sebagai unsur laki-laki. Lumpang batu, dolmen, balok batu, dan batu datar yang bersifat horizontal adalah melambangkan unsur perempuan. Konsep laki-laki dan perempuan tersebut merupakan simbolik dari kesuburan, sesuai konsep berpikir dalam budaya mistis, kemudian pada masa tradisi lebih lanjut disebut atau dikenal dengan istilah "lingga - yoni".

Patung megalitik Pasemah adalah patung megalitik khas Indonesia, karena tidak ditemukan patung-patung megalitik lainnya yang sezaman dan sejenis (dead monuments) dengan patung megalitik di Pasemah, yang bersifat dinamis piktorial dan cenderung realistik, dengan perupaan sosok (kepala, badan, kaki dan tangan) secara lengkap. Patung megalitik Pasemah merupakan karya patung megalitik khususnya media batu yang terbaik di zamannya, karena telah menggunakan teknologi berupa mata pahat yang terbuat dari logam, sehingga 
para pembuatnya dapat menerapkan kemampuan teknis mematungnya secara maksimal.

Budaya megalitik di bumi Pasemah secara keseluruhan merepresentasikan budaya dari suatu masyarakat yang bersifat agraris dengan pola ladang, hal ini tercermin terutama dari keberadaan artefak-artefak megalitik berupa lumpang batu, serta tampilnya patung dengan sosok objek manusia dan atau binatang di beberapa situs megalitik Pasemah. Lumpang batu dengan lubangnya yang bervarian satu, dua, dan empat tentu secara fungsional mengindikasikan adanya ragam jenis biji-bijian hasil perkebunan, yang harus ditumbuk untuk sarana dalam ritual tertentu dengan masing-masing lubang berbeda.

Patung-patung megalitik di Pasemah tidak mengenal adanya pengulangan bentuk yang persis sama, artinya pada masing-masing patung visual atau perupaannya selalu berbeda atau tidak ada yang sama, baik untuk sosok manusia juga binatang. Sedangkan kesamaan yang ada terutama terletak pada bahan atau medianya berupa jenis batuan andesit, dan beberapa kecenderungan kesamaan lainnya, seperti tema, gaya perupaan, tidak berdiri tegak, wajah cenderung menengadah, bergelang kaki dan gelang tangan dari lempengan logam, bersama gajah, kerbau, ular, dan atau yang lainnya. Masing-masing patung yang berbeda namun sekaligus memiliki beberapa kesamaan ini dikenal dan disebut juga sebagai patung yang bersifat "tunggal - jamak", yang mana inipun menjadi salah satu dari ciri khas patung megalitik di Pasemah.

\section{Daftar Pustaka}

[1] Kusumawati, Ayu. 2003. Pustaka Wisata Budaya Megalitik Bumi Pasemah, Departemen Pendidikan Nasional, Jakarta.

[2] Bagyo Prasetyo. 2004. Religi pada Masyarakat Prasejarah di Indonesia, Departemen Kebudayaan dan Pariwisata, Jakarta.

[3] Wiyana, Budi. 1996. Survei Situs-situs Megalitik di Kabupaten Lahat Provinsi Sumatra Selatan, Balai Arkeologi Palembang.

[4] Sumadio, Bambang, Bintarti, D.D., Edi Sedyawati, Soekmono, R.,Wahyono Martowikrido, Suwati Kartiwa, Hardjonagoro, K.R.T., Soedarmadji Damais. 1992. Pusaka Art of Indonesia, Archipelago Press, Singapore.

[5] Hartoko, Dick. 1983. Manusia dan Seni, Yayasan Kanisius, Yogyakarta.

[6] Colin, Didier. 2000. Dictionary of Symbols, Myths, and Legends, Hachette.

[7] Hoop, van der A.N.J.Th.A.Th. 1932. MegalithicRemains in SouthSumatra, Translated by William Shirlaw, Printed and Published by W.J. Thieme \& Cie Zutphen, Netherland. 
[8] I Gede A.B. Wiranata. 2002. Antropologi Budaya, Citra Aditya Bakti, Bandung.

[9] Tresidder, Jack. 2004. The Complete Dictonary of Symbols, Duncan Baird Publishers, London, hal 188.

[10] Sumardjo, Jakob. 2000. Filsafat Seni, ITB, Bandung.

[11] Koentjaraningrat. 1974. Kebudayaan, Mentalitas dan Pembangunan, Gramedia, Jakarta.

[12] 1997. Manusia dan Kebudayaan Indonesia, Djembatan Jakarta.

[13] Kusnadi, dkk. 1979. Sejarah Seni Rupa Indonesia, Depdikbud, Jakarta.

[14] Subagya, Rachmat. 1981. Agama Asli Indonesia, Penerbit Sinar Harapan dan Yayasan Cipta Loka Caraka, Jakarta.

[15] Soekmono, R. 1973. Pengantar Sejarah Kebudayaan Indonesia, Yayasan Kanisius, Jakarta.

[16] Yudoseputro, Wiyoso. 1998. The Early Roots of Indonesian Art, Indonesian Heritage Visual Art, Volume Editor by Hilda Soemantri, Archipelago Press.

[17] Yunus, Yulius. 1970. Seni Rupa Prasejarah Eropa, FPBS - Institut Keguruan dan Ilmu Pendidikan (IKIP), Bandung. 